\title{
Cyanobacterial diversity and bioactivity of inland hypersaline microbial mats from a desert stream in the Sultanate of Oman
}

\author{
Raeid M. M. Abed ${ }^{1 *}$, Sergey Dobrestov ${ }^{2}$, Samiha Al-Kharusi $^{1}$, Angela Schramm ${ }^{3}$, \\ Barry JuPP ${ }^{4} \&$ Stjepko GoluBIC ${ }^{5}$
}

${ }^{1}$ Biology Department, College of Science, Sultan Qaboos University, P. O. Box: 36, PC 123, Al Khoud, Sultanate of Oman; * corresponding author e-mail: rabed@squ.edu.om, Tel: +968-24141450

${ }_{2}$ Marine Science and Fisheries Department, College of Agricultural and Marine Sciences, Sultan Qaboos University, P. O. Box: 34, PC 123, Al Khoud, Sultanate of Oman

${ }^{3}$ Max-Planck Institute for Marine Microbiology, Celsiusstraße 1, D-28359 Bremen, Germany

${ }^{4}$ Marine Pollution Monitoring Section, Ministry of Environment \& Climate Affairs, P.O. Box 175 Mina Al Fahal P.C, 116, Muscat, Sultanate of Oman.

${ }^{5}$ Biological Science Center, Boston University, 5 Cummington str. Boston, MA 02215, USA

\begin{abstract}
The cyanobacterial layer (1-3 mm) of microbial mats of Wadi Muqshin, Sultanate of Oman, in hypersaline continental pools near the Empty Quarter desert were analyzed for cyanobacterial diversity, pigments composition and antibacterial and quorum sensing inhibition activities at the microbial community level. The salinity of the ponds reached up to $75 \%$, the temperature was around $49{ }^{\circ} \mathrm{C}$ and the salt composition was similar to seawater. Cyanobacteria in pools containing coccoid and filamentous forms similar to those normally found in salt ponds and in intertidal flats were found. Among the observed taxa were Microcoleus chthonoplastes, Spirulina subsalsa, Johannesbaptistia pellucida, Chroococcidiopsis sp., Aphanocapsa sp., Chroococcus sp., Gloeocapsa sp., Schizothrix sp. and Leptolyngbya sp. Using high performance liquid chromatography (HPLC), the pigments chlorophyll $a$, scytonemin, chlorophyllid $a, \beta$-carotene and fucoxanthin were detected, with the highest concentrations obtained for the ultra-violet (UV) sunscreen pigment scytonemin. The chemical extracts of the microorganisms in the mats cyanobacterial layer exhibited antibacterial activity against 3 out of 9 tested pathogenic bacterial strains and showed quorum sensing inhibition activity against the reporters Agrobacterium tumefaciens NTL4 (pZLR4) and Salmonella enterica S235 but not Chromobacterium violaceum CV017. We conclude that the studied inland hypersaline microbial mats harbor similar diversity to their counterparts in intertidal flats and evaporation ponds and could produce chemical compounds that are of biotechnological significance.
\end{abstract}

Key words: Cyanobacterial mats, Cyanobacteria, Pigments, Bioactivity, Quorum sensing, Antimicrobial

\section{Introduction}

Cyanobacterial mats are dense, stratified microbial agglomerations that develop well in hypersaline habitats because of the limited grazing activities (JAVOR \& CASTENHOLZ 1984; COHEN 1989; FARMER 1992). These mats are composed of different physiological groups of microbes such as photoautotrophic, photoheterotrophic, chemoautotrophic, and heterotrophic organisms (van Gemerden 1993; Stal 1995). Oxygenic photosynthesis is mainly performed by cyanobacteria in the top few millimeters of the mats, resulting in the development of strong oxygen gradients and the production of organics that are utilized by heterotrophic bacteria (STAL 1995; BATESON \& WARD 1988). While most described hypersaline microbial mats have been found in intertidal flats and salt evaporation ponds, very few were studied from inland lakes and streams (JoNKERs et al. 2003). Recently, we discovered a well-developed hypersaline mat system in a desert stream (Wadi Muqshin) in the Sultanate of Oman, bordering dunes of the Empty Quarter (JuPP et al. 2008). The Wadi is located inland around $200 \mathrm{~km}$ from the Arabian Sea coast and consists of a series of stagnant, hypersaline pools with salinities ranging from 70 $\%$ to $350 \%$. The flooding and recharge regimes of these pools appear to rely on deep (300-400 m) 
groundwater aquifers, thousands of years old. The cyanobacterial diversity and their properties and interaction with other microorganisms in these mats have never been studied.

Since microbial mats contain many physiological groups of bacteria living in close proximity, they are believed to be a rich sourc of bioactive metabolites (BURJA et al. 2001; Gerth et al. 2003; Dahms et al. 2006). Recently, heterotrophic bacteria as well as cyanobacteria isolated from permenantly cold Antarctic microbial mats have been shown to exhibit different bioactivities (BIONDI et al. 2008; RoJAs et al. 2009). Out of 51 cyanobacterial strains, 17 and 25 showed antimicrobial (i.e. bacterial and fungal) and cytotoxic activities, respectively (BIONDI et al. 2008). While 122 out of 723 heterotrophic bacteria showed antibacterial activities, only few had antifungal activity (ROJAS et al. 2009). Thermostable enzymes, anticancer, antifungal and antimicrobial compounds have also been isolated from hot spring mats and marine biofilms (KRISTJANSSON 1989; FenICAL 1993; Zhang et al. 2005; Tirawongsarou et al. 2008). Studies have demonstrated the ability of cyanobacteria to produce the quorum sensing acyl homoserine lactones, involved in cell-to-cell communications (BRAUN \& BACHHOFEN 2004; SHARIF et al. 2008). While most investigations on bioactive compounds were performed using isolated species, little was done to show whether mixed microbial communities of mats exhibit these bioactivities under natural conditions.

In this study, we investigated the hypersaline microbial mats from Muqshin, Oman for their water chemistry, cyanobacterial diversity (using direct microscopy), pigment composition and the ability of their communities to exhibit antibacterial and quorum sensing inhibition activties. The main objective of the study was to establish the baseline information about the cyanobacterial diversity and the potential biotechnological applications of these mats.

\section{Materials and Methods}

Site description and sample collection. The mat samples were collected from Wadi Muqshin in southern Oman in the Nejd hydrogeology area of the Dhofar Region (Fig. 1). The wadi contains dome-shaped laminated microbial mats (Fig. 1) with further information on the hydrogeology, mineralogy and enzyme activity of these mats given in Jupp et al. (2008). The Wadi pools are flooded over winter and then evaporated through summer months giving extremely hypersaline conditions. Annual evaporation data are lacking for the site but are likely to be extreme. Mat pieces were collected in May 2008 from the sides

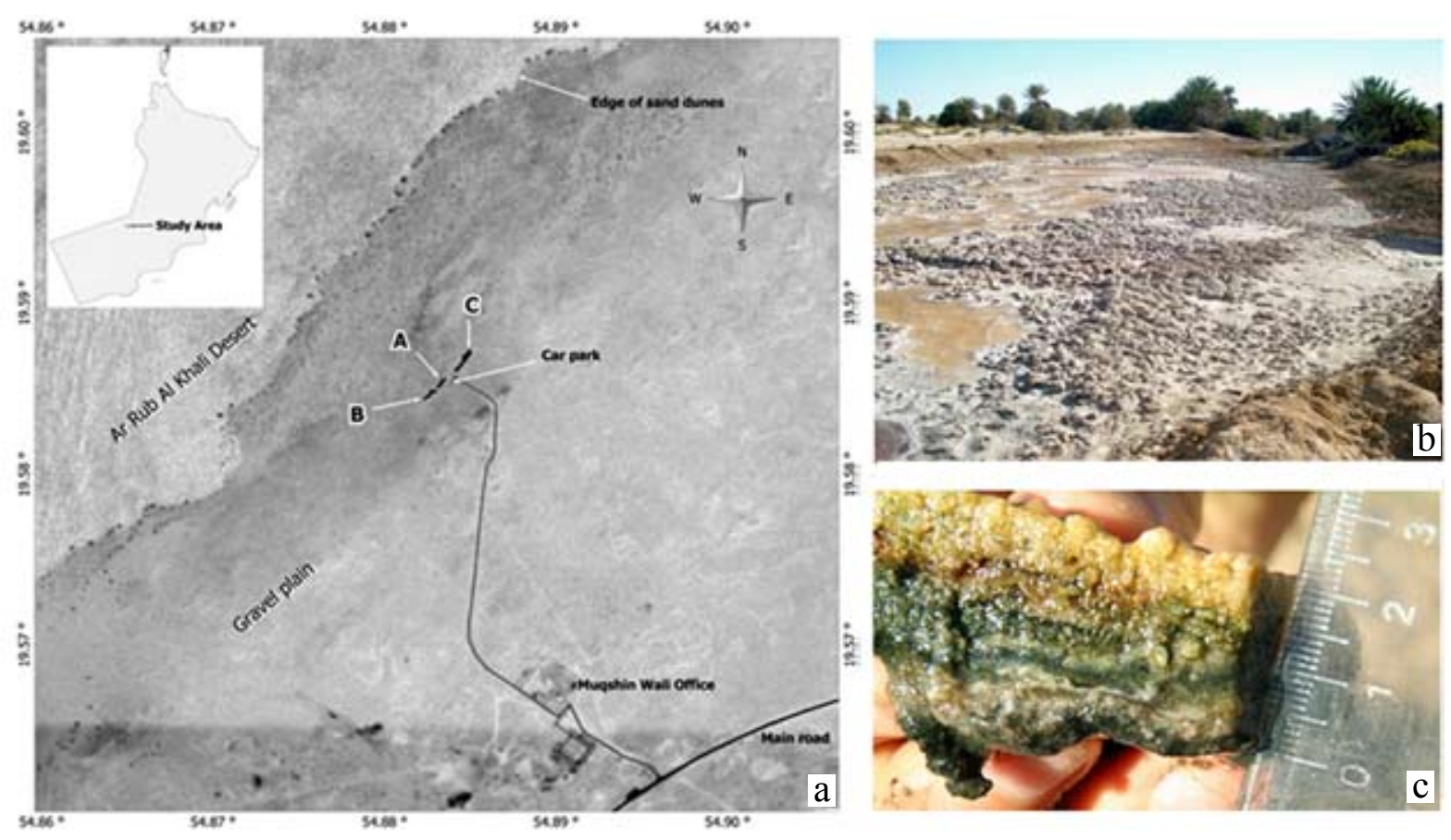

Fig. 1. (a) Map of Wadi Muqshin located close to the empty quarter desert (Ar Rub Al Khali Desert), (b) photograph showing the Wadi with dry and inundated mats, note the precipitated salts on dry mats (c) laminated cyanobacterial mat used in this study. 
Table 1. Field data at Wadi Muqshin sites at time of sampling (29 May 2008).

\begin{tabular}{|c|c|c|}
\hline \multirow[t]{2}{*}{ Parameter§ } & \multicolumn{2}{|c|}{ Hypersaline Microbial mats } \\
\hline & Mat A & Mat B \\
\hline Lat/Long coordinates & N $19^{\circ} 35.10^{\prime} ;$ E $54^{\circ} 53.06^{\prime}$ & $\mathrm{N} 19^{\circ} 35.04^{\prime} ; \mathrm{E} 54^{\circ} 52.89$ \\
\hline UTM coordinates & 278073 E; $2166935 \mathrm{~N}$ & 277777 E; $2166833 \mathrm{~N}$ \\
\hline Elevation (m a.m.s.l.) & 100 & 114 \\
\hline Temp. $\left({ }^{\circ} \mathrm{C}\right)$ & 49 & 36.5 \\
\hline pH & 8.5 & 8.26 \\
\hline Conductivity $\left(\mathrm{mS} . \mathrm{cm}^{-1}\right)$ & 80.9 & 67.6 \\
\hline Salinity $(\%)$ & 74 & 61 \\
\hline Total alkalinity* & 233 & 224 \\
\hline Total hardness* & 18.054 & 15.950 \\
\hline TDS (theoretical)* & 75.931 & 66.056 \\
\hline Sodium* & 21.768 & 18.679 \\
\hline Potassium* & 749 & 619 \\
\hline Magnesium* & 3.739 & 3.289 \\
\hline Calcium* & 1.043 & 948 \\
\hline Manganese* & $<0.05$ & $<0.05$ \\
\hline Iron* & $<0.05$ & $<0.05$ \\
\hline Chloride* & 33.152 & 30.493 \\
\hline Sulphate* & 15.293 & 11.854 \\
\hline Nitrate- $\mathrm{N}\left(\mathrm{NO}_{3}{ }^{-} \mathrm{N}\right)^{*}$ & 0.8 & 2 \\
\hline Bicarbonate $\left(\mathrm{HCO}_{3}^{-}\right)^{*}$ & 284 & 237 \\
\hline $\mathrm{Sr}^{*}$ & 39.1 & 26.8 \\
\hline $\mathrm{F}^{*}$ & n.d. & n.d. \\
\hline
\end{tabular}

and the centre of two pools (termed as mat A and B), and were cut carefully using a sterile scalpel and stored in petri plates. The collected mats differ in appearance, texture and salinity. Field measurements of pools included temperature by electronic probes, $\mathrm{pH}$ by meter and salinity by an Atago S-10E Hand Refractometer.

Microscopy of cyanobacteria and pigment analysis. The cyanobacterial top layer of the mats $(1-3 \mathrm{~mm})$ was excised under a dissecting microscope with a clean scalpel blade and sterile forceps. This delimited the analyses to populations that are potentially active as oxygenic phototrophs (primary producers). Samples were torn apart, mounted in water on a microscope glass slide and observed using transmitted light, phase contrast and fluorescence microscopy. Different morphotypes were identified and photographed. Three cores from each mat sample were observed microscopically to ensure a good overall representation of resident morphotypes.

Pigments were extracted from triplicate samples with ice-cooled $90 \%$ acetone after sonication and incubation at $-20{ }^{\circ} \mathrm{C}$ for $24 \mathrm{~h}$. The supernatants

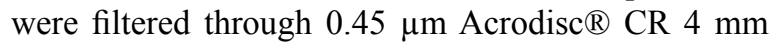
syringe filter (Pall Gelman Laboratory, USA). The extraction was carried out on ice under dim light. The pigments were analyzed using reverse phase high performance liquid chromatography (HPLC) that consisted of a Waters 996 photo diode array detector (PDA) and a Waters 2690 separation module (Waters, Massachusetts, USA). A $125 \times 4.6 \mathrm{~mm}$ vertex column packed with Eurospher-100 C18 of $5 \mu \mathrm{m}$ particle size was used (Knauer GmbH, Berlin, Germany). The pigments were identified by comparing the retention time and the spectrum with commercially available pigment standards (form DHI Water and Environment, Denmark and Merck, Germany).

Antibacterial and quorum sensing ihibiting compounds. Two $\mathrm{kg}$ of the mats were extracted in 1:1 methanol: ethyl acetate (EA) (Fisher Scientific, USA) and kept under the hood for a week to dissolve natural products. Extracted compounds were separated by direct liquid-liquid separation (RICHARDO 1997) and 
Table 2. Antimicrobial and quorum sensing inhibitory activities of ethyl acetate (EA) and methanol (MeOH) extracts of the hypersaline cyanobacterial mats from Muqshin, Oman.

\begin{tabular}{|c|c|c|c|c|}
\hline & \multicolumn{4}{|c|}{ Hypersaline microbial mats } \\
\hline & \multicolumn{2}{|c|}{ Mat A } & \multicolumn{2}{|c|}{ Mat B } \\
\hline & EA & $\mathrm{MeOH}$ & EA & $\mathrm{MeOH}$ \\
\hline \multicolumn{5}{|l|}{ Antibacterial activity } \\
\hline Staphylococcus aureus & ++ & - & ++ & - \\
\hline Streptococcus pyrogenes & ++++ & ++ & +++ & +++ \\
\hline Streptococcus pneumoniae & - & - & - & - \\
\hline Enterococcus feacalis & - & - & - & - \\
\hline Esherichia coli & - & - & - & - \\
\hline Shigella sp. & - & - & - & - \\
\hline Salmonella sp. & - & - & - & - \\
\hline Proteus sp. & - & - & - & - \\
\hline Pseudomonas aeruginosa & +++ & - & +++ & - \\
\hline \multicolumn{5}{|l|}{ Quorum sensing inhibition } \\
\hline Agrobacterium tumefaciens C6HSL & +++ & - & ++++ & - \\
\hline Salmonella enterica sp. S235 & ++ & - & ++ & - \\
\hline Chromobacterium violaceum $\mathrm{CV} 017$ & - & - & - & - \\
\hline
\end{tabular}

For antibacterial activity: (-) no inhibition; (+) $0.1-0.5 \mathrm{~cm}$; (++) $0.6-1 \mathrm{~cm}$; (+++) $1.1-1.5 \mathrm{~cm}$; $(++++)$ B16> $1.6 \mathrm{~cm}$, diameter of inhibition zone

For Quorum sensing: (-) no inhibition; $(+)>150 \mathrm{mg}$; (++) 51-150 mg; (+++) 11-50 mg; (++++) 1-10 mg, wet weight of the extract

samples were re-extracted again for another week using the same solvents. Combined extracts were evaporated using a rotary evaporator (Büchli, Switzerland) till dryness. Before the bioassays (see below), the resulted EA and methanol extracts were dissolved in methanol (Fisher Scientific, USA) and water, correspondingly.

Disc diffusion bioassay was used to test these extracts for the presence of antibacterial activity. Nine pathogenic bacteria obtained from the culture collection of Sultan Qaboos University hospital: Staphylococcus aureus, Streptococcus pyogenes ( $\beta$ haemolytic), Streptococcus pneumoniae ( $\alpha$ haemolytic), Enterococcus faecalis ( $\alpha$ haemolytic), Escherichia coli, Shigella sp., Salmonella sp., Proteus sp. and Pseudomonas aereginosa were tested against all extracts according to DoBRETSOV \& QIAN (2002). The formation of inhibition zones was measured. All tests were repeated in triplicates and paper discs containing solvents were used as controls.

Quorum sensing inhibition (QSI) bioassay was performed using all extracts against QS reporters Chromobacterium violaceum CV017 (CHERNIN et al. 1998), Agrobacterium tumefaciens NTL4 (pZLR4) (CHA et al. 1998) and Salmonella enterica S235 (TEPLITSKI \& AhMER 2005). All bioassays were performed according to DOBRETSOv et al. (2010) in 96 cell well plates containing different concentrations of extracts.

\section{Results}

\section{Water quality of Muqshin pools}

At the time of sampling, the salinity in the two ponds ranged between $61-74 \%$ and the conductivity was between $67-81 \mathrm{mS} \mathrm{cm}^{-1}$. The temperature was measured at the mat surface and was found to be 49 and $36^{\circ} \mathrm{C}$ in mat $\mathrm{A}$ and $\mathrm{B}$, respectively (Table 1 ), although it can drop down to $18-23{ }^{\circ} \mathrm{C}$ during winter. The water of the ponds was slightly alkaline with a $\mathrm{pH}$ around 8.5 . These waters under winter flooded conditions (i.e. in February) showed lower salinities than in summer, due to less evaporation, but still have high hardness $\left(>15,000 \mathrm{mg} . \mathrm{l}^{-1}\right)$ and are hypersaline with sodium levels up to $23,000 \mathrm{mg} .1^{-1}$ and chloride levels up to $35,000 \mathrm{mg} \cdot 1^{-1}$. The salt composition is more or less similar to the seawater composition, although concentrations are slightly higher in Muqshin water. 


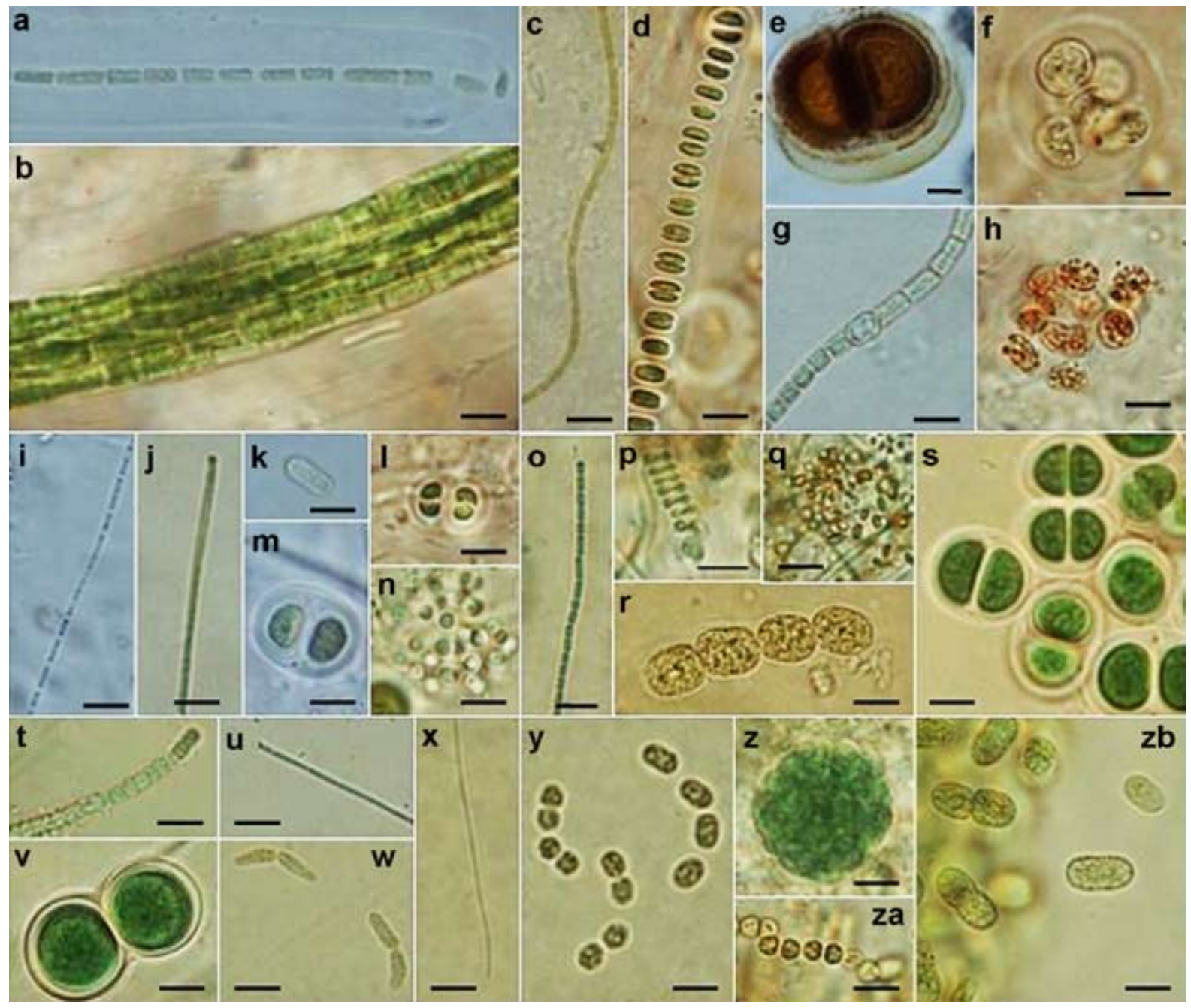

Fig. 2. (a) Microcoleus chthonoplastes, filament with a single trichome; (b) Microcoleus chthonoplastes, filament with a bundle of trichomes; (c) Leptolyngbya sp. 1; (d) Johannesbaptistia pellucida; (e) Chroococcus sp.; (f) Aphanocapsa sp.1; (g) Schizothrix splendida, degraded trichome; (h) Chromatium okenii, a encapsulated sulfur purple proteobacterium; (i) Leptolyngbya sp. 2; (j) Leptolyngbya sp. 3; (k) Aphnothece sp. 1; (1) Chroococcus sp. 1; (m) Chroococcus sp. 2; (n) Aphanocapsa sp. 2.; (o) Leptolyngbya sp. 4; (p) Spirulina subsalsa; (q) Aphanocapsa sp.3; (r) Romeria sp.; (s) Chroococcus submarinus; (t) Pseudanabaena sp.; (u) Leptolyngbya sp. 5; (v) Chroococcus sp. 3; (w) Dactylococcopsis sp.; (x) Leptolyngbya sp. 6; (y) Aphanothece sp. 2; (z) Xenococcus sp.; (za) Aphanothece sp. 3; (zb) Aphanothece sp. 1.

\section{Cyanobacterial diversity as revealed by direct microscopy}

The diversity of cyanobacteria in the hypersaline mats of Muqshin were studied by direct microscopy and both mats showed similar types. Several different filamentous and coccoid cyanobacteria were observed in these mats (Fig. 2). Filaments of taxonomic affinity to Schizothrix were observed with a one to two trichomes surrounded by wide hyaline sheaths often with disconnected cells (Fig. 2a). Similarly damaged slightly shrunken and disconnected cells were documented in Microcoleus chthonoplastes (Fig. 2b), which were common in pools with fluctuating salinities. This cyanobacterium was apparently not growing at the time of collection, but showed good preservation of trichomes bundled in a common sheath and with well preserved pigments. Very thin cyanobacteria with filaments containing consistently single trichomes within thin but firm sheaths, but frequently abandoning the sheats when under environmental stress occured within colonies of other cyanobacteria or within common gelatinous matter secreted by the entire microbial community (Fig. 2c, i, j, o, u, x). These cyanobacteria are classified as Leptolyngbya, although this genus proved to be polyphyletic according to $16 \mathrm{~S}$ rRNA gene clustering (CASTEnHOLZ 2001). The observed organisms show consistent distinction in cell sizes, shapes and separation after division, thus probably belonging to different taxonomic entities. Similar diversity of forms was observed among coccoid 


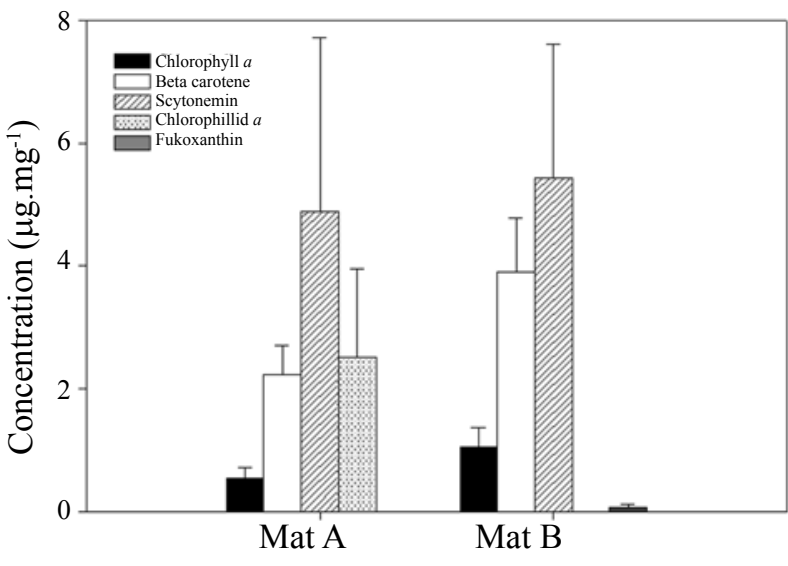

Fig. 3. Comparsion of the distribution of intracellular and extracellular pigments in the two studied cyanobacterial mats. Note that the highest concentration is for the UV pigment scytonemin.

cyanobacteria that divide in one dimension, with elongated oval to cylindrical cells that produce structureless exopolymer gel intermittent to cell division. These are classified as Aphanothece spp. (Fig. 2 k, r, y, zb). The chroococcalean cyanobacterium Johannesbaptistia pellucida (Fig. $2 \mathrm{~d}$ ), is sharing the same orientation in cell division with Aphanothece, but has distinctly different cell proportions: the cells are much shorter than wide forming pseudofilaments. The organism is common in brackish to hypersaline ponds along tropical coasts. Other coccoid cyanobacteria, which divide in two or three alternating dimensions by successive cell cleavage, were represented in the studied ponds by several species of Chroococcus (Fig. 2e, 1, m, s) including a probable new species (Fig. 2e). Other cyanobacteria include Gloeocapsa, Aphanocapsa and a Pleurocapsalean form, close to Chroococcidiopsis. Among filamentous forms, Spirulina subsalsa (Fig. 2p) and trichomes similar to Anabaena were observed (Fig. 2t).

\section{Pigment analysis}

Five pigments (chlorophyll $a$, scytonemin, chlorophyllid $a, \beta$-carotene and fucoxanthin) were detected in the studied mats (Fig. 3). Chlorophyllid $a$ is a known precursor of chlorophyll $a$ and all these pigments originate mainly from oxygenic phototrophs. Chlorophyllid $a$ was detected in mat A but not B whereas fucoxanthin was detected in mat B but not A. The concentration of the remaining pigments was comparable and did not vary much among the two samples. The highest concentrations were obtained for the pigment scytonemin and reached about 6 times higher than chlorophyll $a$.
Antibacterial and quorum sensing activity of cyanobacterial mats extracts

Extracts from the two studied mats showed antibacterial activity against 3 out of 9 tested pathogenic bacterial strains and most activity was observed in methanol extracts. While ethyl acetate (EA) extracts were active against Staphylococcus aureus, Streptococcus pyogenes and Pseudomonas aereginosa, methanol extracts inhibited growth of only Streptococcus pyogenes (Table 2). The EA extracts of the mats showed quorum sensing inhibition activity against Agrobacterium tumefaciens NTL4 (pZLR4) and Salmonella enterica S235, whereas methanol extracts revealed no activity against tested QS reporters (Table 2). The highest QS inhibitory activity was observed for EA extracts of mat B that at concentration of $1-10 \mathrm{mg} \cdot \mathrm{ml}^{-1}$ inhibited QS of A. tumefaciens NTL4 (pZLR4). No activity against Chromobacterium violaceum $\mathrm{CV} 017$ was observed. Concentration of 1-10 mg.ml ${ }^{-1}$ of the EA extracts of mat B inhibited QS of A. tumefaciens NTL4 (pZLR4). At tested concentrations of all extracts were not toxic to all reporters.

\section{Discussion}

Many of the cyanobacteria observed in the Muqshin Wadi hypersaline pools, have been observed in a range of salinities in different parts of the world (CAmpbell \& Golubic 1985; Abed \& GarciaPichel 2001; Jonkers et al. 2003; Richert et al. 2006; CерÁK \& KomÁreK 2010). The detection of Microcoleus chthonoplastes supports the notion that this cyanobacterium is the main mat-building microorganism with a cosmopolitan distribution (Garcia-Pichel et al. 1996). The new species Chroococcus cyanostylon has also been observed in the intertidal flats adjacent to the sabkha plane on the coast of Abu Dhabi, UAE (ABED et al. 2008; Golubic \& ABED 2010) and C. submarinus and Johannesbaptistia pellucida have been observed in coastal ponds of the Rangiroa Atoll, Tuamotu Archipelago, French Polynesia where the salinity ranged and varied over time from brackish to hypersaline; both organisms were obtained in culture and the SSU-sequenced (RICHERT et al. 2006). Those ponds were dominated by two Schizothrix species but these were not cultured or sequenced. Various species of Aphanothece are known from the Solar Lake of Sinai Peninsula, Egypt (CAmpBell \& Golubic 1985). 
Chroococcidiopsis is a polyextremophile, which is frequently found in several types of extreme environment including extremely salty conditions in marshes, as well as hot and cold deserts (GriLLI CAIOla \& Billi 2007). This cyanobacterium has also been found in the intertidal flats of Abu Dhabi (ABED et al. 2008).

The observed strains of Aphanothece, Aphanocapsa, Chroococcidiopsis, Johannesbaptistia, and Microcoleus are known extremophilic cyanobacteria (KARSTEN 1996; NüBEL et al. 2000; ABED et al. 2001, 2008), an observation that is consistent with the prevailing environmental conditions in Wadi Muqshin. Such cyanobacteria have developed several strategies to cope with elevated salinities, including the production of compatible solutes (GALINSKY 1995). Recently, the filaments of Microcoleus chthonoplastes were found to migrate up and down, a process attributed to halotaxis in intertidal mats in order to cope with the continuous fluctuation of salinity (KoHLS et al. 2010). Microcoleus and Chroococcidiopsis are known to tolerate dessication (GRILli GaIOLA et al. 1996; OHAD et al. 2005; Fleming et al. 2007) through the production of polyhydroxyl carbohydrates, which replace the water shell around cellular macromolecules, preventing denaturation (PотTs 1994, 1999). Studies on Chroococcidiopsis strains have demonstrated their ability to survive prolonged desiccation through efficient repair of the DNA damage that occurred during dehydration (BILLI et al. 2000). The elevated levels of solar UV radiation in Wadi Muqshin, especially in summer, favored the growth of scytonemin-producing cyanobacteria such as Chroococcus and Chroococcidiopsis. These cyanobacteria were previously shown to produce scytonemin as a UV sunscreen and the production of this pigment was shown to be stimulated by temperature, UV-A irradiation (Dillon et al. 2002) and periodic desiccation (Fleming \& CASTENHOLZ 2007). Interestingly, Microcoleus chthonplastes, which is not able to produce scytonemin was found to "hide" beneath scytonemin-producing cyanobacteria, a behavior achieving protection of its mobile filaments from UV damage. Scytonemin is an extremely stable pigment, which remains largely intact in the sheaths of desiccated cyanobacteria. A scytonemin-like pigment was found preserved on the surfaces of silicified Proterozoic stromatolites (Golubic \& HofMANN 1976), indicating that protection from solar radiation by extracellular pigments is an ancient adaptation. In an environment with fluctuating water supply and frequent desiccation the persistence of scytonemine may be important during re-hydration and recovery of the entire community of these mats.

Unlike previous studies on bioactive compounds, which focused mainly on screening isolated strains (i.e. BIONDI et al. 2008; RoJAS et al. 2009), we studied here the bioactivity of mixed microbial communities under natural conditions. This approach takes advantage of microbial relationships in natural communities that do not exist in pure cultures. Furthermore, there is a possibility to isolate novel compounds produced by microorganisms that are difficult to cultivate in the laboratory. Such an approach provides not only increased possibilities to discover more versatile secondary metabolites but also increases our understanding of the chemical environment and cell-to-cell relationship in mixed microbial communities. The extracts of the studied mats inhibited growth of 3 out of 9 tested bacterial pathogens. While this may be due to a low antibacterial activity of the extracts, it may also reflect the fact that microorganisms from these mats are not exposed to pathogens and, thus, do not produce antibiotics against them. Mostly ethyl acetate (non-polar) and not methanol (polar) extracts of the mats inhibited the growth of the tested pathogens. Dominance of non-polar antibacterial compounds from isolates of microbial mats has been previously reported (Biondi et al. 2008).

Extracts from the mats communities inhibited QS of Agrobacterium tumefaciens NTL4 (pZLR4) but not Chromobacterium violaceum CV017, which relies on short side chain AHLs. This differential QS activity can be explained by the fact that short side chain AHLs are less stable under extreme environments (DOBRETSOv et al. 2009). Therefore, the production of QS inhibitors against these signal molecules in the investigated communities is possibly not necessary. Inhibitors that suppress one component LuxR-N-acyl homoserine lactones (AHLs) system have been reported in most of previous studies (Dobretsov et al. 2009). In contrast to previous investigations, in this study, we screened extracts for the production of inhibitors that affect the two component GacS/ GacA system (reporter Salmonella enterica S235) in addition to the AHL inhibitors (A. tumefaciens NTL4 and C. violaceum CV017). This system is widely distributed in all $\gamma$-Proteobacteria and used 
to respond and adapt to different environmental conditions (Teplitski \& AhMer 2005). We observed a strong inhibition of the $\mathrm{GacS} / \mathrm{GacA}$ system by ethyl acetate extracts of hypersaline mats. None of QS inhibitors of the GacS/GacA system have been isolated so far (DoBRETSOv et al. 2009); this fact highlights the biotechnological potential of microbial communities from Muqshin hypersaline mats that should be investigated in future studies.

One question that is raised from this study is why hypersaline mat microorgansims produce antibacterial and antiquorum sensing compounds under in situ conditions? It is conceivable that microorganisms in these ecosystems produce bioactive compounds with the effect or regulating attachment and growth of other microorganisms in the course of formation of stable communities. Although production of antibacterial and antiquorum sensing compounds by entire microbial communities has not been investigated previously, other studies demonstrated that microorganisms within biofilms are capable of coordinating their behavior by production of quorum sensing compounds (Huan et al. 2007; Decho et al. 2009). A recent study has demonstrated the ability of microbial mats to produce a diverse array of AHLs (Decho et al. 2009). The production of these compounds and their concentrations showed age (Huang et al. 2007) and day-tonight (DECHO et al. 2009) variations among different biofilms. Therefore, screening of mixed microbial communities for production of chemical compounds may provide a new strategy to discover novel bioactive compounds and may be used as an initial screening step before extensive and timeconsuming isolation of individual microorganisms is done.

\section{Acknowledgments}

The study has been carried out with the support of the Sultan Qaboos University, Muscat, Oman, and the Max Planck Institute for Marine Microbiology, Breman, Germany. The international exchange and collaboration was supported by the Hanse Institute for Advanced Studies, Delmenhorst, Germany and by the Alexander-von-Humboldt Foundation, Bad Godesberg, Germany.

\section{References}

ABED, R.M.M \& GARCiA-Pichel, F. (2001): Long-term compostional changes after transplant in a microbial mat cyanobacterial community revealed using a polyphasic approach. Environ. Microbiol. 3: 53-62.

Abed, R. M. M., Kohls, K., Schoon, R. Scherf, A-K., Schacht, M., Palinska, K. A., Al Hassani, H., Hamza, W., Rullkötter, J \& Golubic, S. (2008): Lipid biomarkers, pigments and cyanobacterial diversity of microbial mats across intertidal flats of the arid coast oft he Arabian Gulf (Abu Dhabi, UAE). - FEMS Microbiol. Ecol. 65: 449-462.

BAteson, M. M. \& WARD, D. M. (1988): Photoexcretion and fate of glycolate in a hot spring cyanobacterial mat. App. Environ. Microbiol. 54: 1738-1743.

Billi, D., Friedmann, E. I., Hofer, K. G., Gaiola, M. G. \& OCAMPO-FriedMANN, R. (2000): Ionizingradiation resistance in the desiccation-tolerant cyanobacterium Chroococcidiopsis. - App. Environ. Microbiol. 66:1489-1492.

Biondi, N. M., Tredici, A., Taton, A., Wilmotte, D., Hodgson, D., Losi, D. \& Marinelli, M. (2008): Cyanobacteria from benthic mats of Antarctic lakes as a source of new bioactivities. - J. App. Microbiol. 105: 105-115.

Braun, E. \& Bachofen, R. (2004): Homoserinelactones and microcystin in cyanobacterial assemblages in Swiss lakes. - Hydrobiologia 522: 271-280.

Burja, A.M., Banaigs, B., Abou-Mansour, E., Burgess, G. \& Wright, P.C. (2001): Marine cyanobacteria - a prolific source of natural products. - Tetrahedron 57: 9347-9377.

Campbell, S.E. \& Golubic, S. (1985): Benthic cyanophytes (cyanobacteria) of Solar L a k e (Sinai). -Algological Studies 38/39: 311-329.

Cepák, V. \& KomÁrek, J. (2010): Cytomorphology of six halotolerant coccoid cyanobacteria using DAPI fluorescent and transmission electron microscopy, compared with molecular data. Fottea 10: 229-234.

Chernin, L.S., Winson, M.K., Thompson, J.M., Haran, S. Bycroft, B.W., Chet, I., Williams, P. \& Stewart, G.S. (1998): Chitinolytic Activity in Chromobacterium violaceum: substrate analysis and regulation by quorum sensing. $-\mathrm{J}$. Bacteriol. 180: 4435-4441.

Chao, C., Gao, P., Chen, Y.C., Shaw, P.D. \& Farrand, S.K. (1998): Production of acyl-homoserine lactone quorum-sensing signals by gramnegative plant-associated bacteria. - Molecular Plant-Microbe Interactions 11: 1119-1129.

CoHEn, Y. (1989): Photosynthesis in microbial mats and its relation to the sulfur cycle: a model 
for microbial sulfur interactions. - In. COHEN, Y. \& Rosenberg, E. (eds): Microbial mats: physiological ecology of benthic microbial communities. - pp. 22-36, American Society for Microbiology, Washington, D.C.

Dahms, H-U., Ying, X. \& Pfeiffer, C. (2006): Antifouling potential of cyanobacteria: a minireview. - Biofouling 22: 317-323.

Decho, A.W., Visscher, P.T., Ferry, J., Kawaguchi, T., He, L., Przekop, K.M., Norman, R. S. \& REID, R.P. (2009): Autoinducers extracted from microbial mats reveal a surprising diversity of $\mathrm{N}$-acylhomoserine lactones (AHLs) and abundance changes that may relate to diel $\mathrm{pH}$. Environ. Microbiol. 11: 409-420.

Dillon, J.G., Tatsumi, C.M., Tandingan, P.G. \& Castenholz, R.W. (2002): Effect of environmental factors on the synthesis of scytonemin, a UV-screening pigment, in a cyanobacterium (Chroococcidiopsis sp.). Arch. Microbiol. 177:322-331.

Dobrestsov, S. \& Qian, P. Y. (2002): Effect of bacteria associated with the green alga Ulva reticulata on marine micro- and macrofouling. - Biofouling 18: 217-228.

Dobretsov, S., Teplitski, M. \& Paul, V. (2009): Quorum sensing in the marine environment and its relationship to biofouling. - Biofouling 25: $413-427$.

Dobretsov, S., Teplitski, M., Alagely, A., Gunasekera, S. \& PAUl, V. (2010): Malyngolide from the cyanobacterium Lyngbya majuscula interferes with QS circuitry. - Environ. Microbiol. Reports 2: 739-744.

FARMER, J.D. (1992): Grazing and bioturbation in modern microbial mats. - In SCHOPF, J. W.

\& KleIn, C. (eds): The Proterozoic biosphere: a multidisciplinary study. - pp. 247-251, Cambridge university press, Cambridge.

Fenical, W. \& Jensen, P.R. (2006): Developing a new resource for drug discovery: marine actinomycete bacteria. - Nat. Chem. Biol. 2: 666-673.

Fleming, E.D., Bebout, B.M. \& Castenholz, R.W. (2007): Effects of salinity and light intensity on the resumption of photosynthesis in rehydrated cyanobacterial mats from Baja California Sur, Mexico. - J. Phycol. 43:15-24.

Fleming, E.D. \& Castenholz, R.W. (2007): Effects of periodic desiccation on the synthesis of the UV-screening compound, scytonemin, in cyanobacteria. - Environ. Microbiol. 9: 14481455.

GALINSKY, E.A. (1995): Osmoadaptation in bacteria. Adv. in microb. physiol. 37: 274-328.

Garcia-Pichel, F., Prufert-Bebout, L. \& Muyzer, G. (1996): Phenotypic and phylogenetic analses show Microcoleus chthonoplastes to be a cosmopolitant cyanobacterium. - App. Environ. Microbiol. 62: 3284-3291.

Gerth, K., Pradella, S., Perlova, O., Beyer, S. \& Müller, R. (2003): Myxobacteria: proficient producers of novel natural products with various biological activities - past and future biotechnological aspects with the focus on the genus Sorangium. - J. Biotechnol. 106: 233253.

Golubic, S. \& Abed, R.M.M. (2010): Entophysalis mats as environmental regulators. - In: SECKBACH, J. \& OREN, A. (eds): Microbial Mats: Modern and ancient microorganisms in stratified systems. - pp. 239-251, Springer Verlag, Dordrecht Heidleberg London New York.

Golubic, S. \& Hofmann, H.J. (1976): Comparison of modern and mid-Precambrian Entophysalidaceae(Cyanophyta)instromatolitic algal mats: cell division and degradation. $-\mathrm{J}$. Paleontol. 50: 1074- 1082.

Grilli Gaiola, M., Billi, D. \& FriedmanN, E.I. (1996): Effect of desiccation on envelopes of the cyanobacterium Chroococcidiopsis sp. (Chroococcales). - Eur. J. Phycol. 31:97-105.

Grilli Gaiola, M. \& Billi, D. (2007): Chroococcidiopsis from desert to mars. - In: SECKBACH, J. (ed.): Algae and cyanobacteria in extreme environments. - pp. 553-568, Springer, Heidelberg.

Huang, Y.L., Dobretsov, S., Ki, J.S., Yang, L.H. \& QIAN, P.Y. (2007): Presence of acyl-homoserine lactone in subtidal biofilm and the implication in larval behavioral response in the polychaete Hydroides elegans. - Microb. Ecol. 54: 384392.

JAVOR, B.J. \& CASTENHOLZ, R.W. (1984): Invertebrate Grazers of microbial mat, Laguna Gurrero Negro, Mexico. - In: Cohen Y., Castenholz, R.W. \& Halvorson, H. O. (eds): Microbial Mats: Stromatolites. - pp. 85-94, Alan R. Liss, Inc, New York.

Jonkers, H.M. Ludwig, R., De wit, R., Pringault, O., Muyzer, G., Nienmann, H., Finke, N. \& DE BEER, D. (2003): Structural and functional analysis of a microbial mat ecosystem from a unique permanent hypersaline inland lake: ' $\mathrm{La}$ Salada de Chiprana' (NE Spain). - FEMS Microbiol. Ecol. 44: 175-189.

Jupp, B.P., Eichenberger, U. \& Cookson, P. (2008): The microbial domes of Wadi Muqshin pools, Sultanate of Oman. - Int. J. Environ. Stud. 65: 685-703.

Karsten, U. (1996): Growth and organic osmolytes of geographically different isolates of Microcoleus chthonoplastes (Cyanobacteria) from benthic microbial mats: response to salinity change. $-\mathrm{J}$. Phycol. 32:501-506.

Kohls, K., Abed, R.M.M., Polerecky, L., Weber, M. \& 
De BeER, D. (2010): Halotaxis of cyanobacteria in an intertidal hypersaline microbial mat. Env. Microbiol. 12: 567-575.

Kristjansson, J.K. (1989): Thermophilic organisms as sources of thermostable enzymes. - Trends Biotechnol. 7: 349-353.

Richert, L., Golubic, S., De Le Gue, R., Herve, A. \& PAYri, C. (2006): Cyanobacterial populations that build 'kopara' microbial mats in Rangiroa, Tuamotu Archipelago, French Polynesia. - Eur. J. Phycol. 41: 259279.

Rojas, J.L., Martin, J., Tormo, J.R., Vicente, F., Brunatic, M., Cicilliato, I., Losi, D., van Trappen, S., Mergaert, J., Swings, J., Marinelli, F. \& Genilloud, O. (2009): Bacterial diversity from benthic mats of Antarctic lakes as a source of new bioactive metabolites. - Marine Genomics 2: 33-41.

Sharif, D.I., Gallon, J., Smith, C.J. \& Dudley, E.D. (2008): Quorum sensing in Cyanobacteria: $\mathrm{N}$-octanocyl-homoserine release and response, by the epilithic colonial cyanobacterium Gloeothece PCC6909. - The ISME Journal 2: 1171-1182.

Stal, L.J. (1995): Physiological ecology of cyanobacteria in microbial mats and other communities. - New Phytol. 131: 1-32.

Teplitski, M. \& Ahmer, M.M. (2005): The control of secondary metabolism, motility, and virulence by the two-component regulatory system BarA/ SirA of Salmonella and other $\gamma$-proteobacteria. - In: Pruss, B.M. (ed.): Global Regulatory Networks in Enteric Bacteria. - pp. 107-132, Research Signpost, Kerala, India.
Tirawongsaroj, P., Sriprang, R., Harnpicharnchai, P., Thongaram, T., Chamreda, V., TANANPONGPipat, S., Pootanakit, K. \& Eurwilaichitr, L. (2008): Novel thermophilic and thermostable lipolytic enzymes from a Thailand hot spring metagenomic library. - J. Biotechnol. 133: 42-49.

Nübel, U., Garcia-Pichel, F., Clavero, E. \& Muyzer, G. (2000): Matching molecular diversity and ecophysiology of benthic cyanobacteria and diatoms in communities along a salinity gradient. - Environ. Microbiol. 2: 217-226.

Ohad, I., Nevo, R., Brumfeld, V., Reich, Z., Tsur, T., YAIR, M. \& KAPLAN, A. (2005): Inactivation of photosynthetic electron flow during desiccation of desert biological sand crusts and Microcoleus sp.-enriched isolates. - Photochem. Photobiol. Sci. 4: 977-982.

Potтs, M. (1994): Desiccation tolerance of prokaryotes. - Microbiol. Mol. Biol. Rev. 58: 755-805.

Potтs, M. (1999): Mechanisms of desiccation tolerance in cyanobacteria. - Europ. J. Phycol. 34:319328.

van Gemerden, H. (1993): Microbial mats: A joint venture. - Mar. Geol. 113: 3-25.

Zhang, L., An, R., Wang, J., Sun, N., Zhang, S., Hu, J. \& KUAI, J. (2005): Exploring novel bioactive compounds from marine microbes. - Curr. Opinion Microbiol. 8: 276-281.

Czech Phycological Society 2011

Recieved Sept 2010

Accepted Dec 2010 